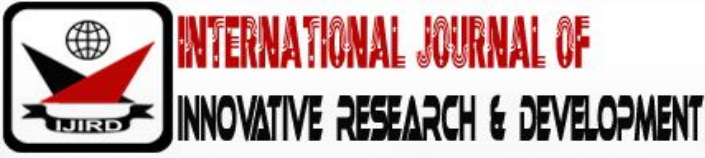

ISSN 2278 - 0211 (Online)

\section{Agency Banking and Accessibility to Financial Services: A Survey of Commercial Banks in the Northern Province of Rwanda}

\author{
Munyengabe Albert \\ Senior Relationship Officer- Operations, Equity Bank Rwanda \\ Kamau Gabriel Kung'u \\ Lecturer, Mount Kenya University, Rwanda
}

\begin{abstract}
:
This research project was on assessing the effects of agency banking on accessibility to financial services in commercial banks in the Northern Province of Rwanda. Agency banking has become one of the essential services in the banking sector in bringing their services closer to the people who are in the remote areas where branches are not present. The purpose of this study was to analyze the effects of agency banking on accessibility to financial services in commercial banks in the Northern Province of Rwanda. The researcher was guided by the following objectives: to investigate how operational structure of agency banking influences customer's access to financial services in commercial banks in Northern Province, to establish the relationship between brand images of agency banking and accessibility to financial services in commercial banks in Northern Province, to determine the effects of agency banking on customer's access to financial services in commercial banks in Northern Province. The study adopted a descriptive research design. The population was 555 agents under which sample size was 233 people found using Yamane formula. The study used stratified and simple random sampling method. Also different research instruments of data collection were used which include: journal, articles, documents analysis and questionnaires. The reliability of the study was tested by carrying out a pilot research and found that Cronbach's Alpha of .831. The data was analyzed using SPSS version21 and data was presented using tables, percentages, means, and standard deviations. To analyze the relationship between two variables, Pearson Chi-Square and Pearson correlation were used to come up with comprehensive results. It was clear from the study that strategic responses to implementation of agency banking as a competitive strategy in enhancing customer's access to financial services included provision of high quality customer service, enhancing operational structure and improving the brand image. The study established that operational structure, brand image and financial services awareness among the rural population are positively correlated $(r=0.805)$ with access to financial services. Access to financial services was greatly enhanced by strategically increasing the proximity of agency banking services, increasing the number of services that could be offered through agency banking and increasing awareness among the population on financial services available at agency banking outlets. The study recommended that Commercial banks should ride on the successes made in agency banking to scale up access to financial services hence financial inclusion by opening up more outlet networks to considerably reduce the distances covered by the rural poor. Moreover the study recommended improvement of brand image of all agent banks operating in the retail market. Finally the study recommended that information and awareness should be put in public to build confidence and trust in agency banking as a secure, efficient and modern way of banking.
\end{abstract}

Keywords: Agency banking, accessibility to financial services, operational structure, brand image, commercial banks in Northern Province Rwanda

\section{Introduction}

Agency banking is one in which banks provide financial services through nonbank agents, such as grocery stores, retail outlets, post offices, pharmacies, or lottery outlets. Agency banking takes customers out of the bank halls to kiosks and villages. Investors have pumped billions into new platforms that offer agency banking services. This model allows banks to expand services into areas where they do not have sufficient capacity to establish a formal branch, which is particularly true in rural and poor areas where as a result a high percentage of people are unbanked. Agency banking is quickly becoming recognized as a viable strategy in many countries for extending formal financial services into poor and rural areas in that agency banking enables clients to store, send and receive electronic money through local agents, rather than travelling to the nearest bank branch (Mulupi, 2011). 
Agency banking has been adopted and implemented with varying degrees of success by a number of developing countries, particularly in Latin America. Brazil is often recognized as a global pioneer in this area since it was an early adopter of the model and over the years has developed a mature network of agency banks covering more than 99\% of the country's municipalities. Other countries in Latin America have followed suit, including Mexico, Peru, Colombia, Ecuador, Venezuela, Argentina and Bolivia (Plok, 2009).

In Africa and Asia continents, the countries that have utilized the agency banking model to expand financial services include Pakistan, Philippines, Kenya, South Africa, Uganda, and India. The regulation, design, and implementation of agency banking vary across countries (Ignacio and Siedek, 2008). The partnership has helped banks to take financial services closer to people, more importantly, to areas that lack them. Kenya being the pioneer of agency banking in Africa changed its banking laws in January 2010, to allow commercial banks offer their services through third-party businesses. The agents operate as satellite branches. The banking concept that is deepening access to financial services is gaining currency in Kenya, where onethird of the population still lacks access to formal banking services (Central Bank of Kenya, 2010).

In Rwanda, agency banking was introduced in 2012, Equity bank being the pioneer. Other banks such as KCB, BK, COGE Bank have followed the suit. These banks have embarked on an important reform to expand banking services to millions of poor household by enabling third party retail agents as a low cost distribution alternative to branches. These agents are increasingly utilized as important distribution channels for financial institutions. Banking agents are usually equipped with a combination of POS card reader, mobile phone, barcode scanner to scan bills for bill payment transactions, PIN pads, and sometimes PCs that connect with the bank's server using personal dial up or other data connection.

Clients that transact at the agent use a magnetic stripe bank card or their mobile phone to access their bank account. Identification of customers is normally done through a PIN, but could also involve biometrics. With regard to the transaction verification, authorization, and settlement platform, banking agents are similar to any other remote bank channel. Agency banking minimizes fixed cost by leveraging existing retail outlets and stores hence financial service providers do not need to invest in their own physical infrastructure and also by using mobile phones rather than POS terminals as technology platform, financial service providers do not even have to incur equipment costs, for each new retail outlet opened. Such a variable cost structure makes the agents economics very simple (Mugambi, 2013).

\subsection{Statement of the Problem}

Agency banking has become one of the essential services in the banking sector in bringing their services closer to the people who are in the remote areas where brick and mortar branches are not present. To move closer and access many customers, commercial banks started to allow other commercial outlets like shops and supermarkets to act in their capacity as formal banks and this was formally launched by National Bank of Rwanda about five years ago. According to the BNR (2013), there will be significant growth in retail deposits amongst commercial banks that had embraced agency banking. Francis (2015) conducted a study on the effects of agency banking on access to financial services in commercial banks in Kenya, The study found that agency banking should be given attention on security measures. A few studies have been conducted on the impact of agency banking on financial services of commercial banks in Rwanda. Aduda, et al. (2013) studied the effect of agency banking on financial inclusion in Kenya. They established that customers with large transactions are unlikely to transact with bank agents because of security risks. Other studies that have been conducted have mainly focused on the impact of agency banking on operational performance of commercial banks. The few studies on the impact of agency banking on accessibility to financial services in commercial banks in Rwanda that have been conducted targeted individual banks and were carried out before many commercial banks embraced agency banking. Unlike the past, today it is common to find one agent providing services of at least three commercial banks at the same outlet. The current study therefore seeks to bridge the gap between what has been previously studied by other researchers by carrying out a research on the effects of agency banking on accessibility to financial services in commercial banks in Rwanda. Although customers have benefited a lot through the agency banking, it is not clear whether the financial services of commercial banks have improved or not as a result of adopting agency banking. This study will attempt to answer the following research question: What are the effects of agency banking on accessibility to financial services in commercial banks in Rwanda?

\subsection{General Objective}

The general objective of the study was to analyze the effects of agency banking on accessibility to financial services in commercial Banks in the Northern Province of Rwanda.

\subsection{Specific Objectives}

- To investigate how operational structure of agency banking influences customer's access to financial services in commercial banks in Northern Province.

- To establish the relationship between brand images of agency banking and accessibility to financial services in commercial banks in Northern Province.

- To determine the effects of agency banking on access to financial services in commercial banks in Northern Province. 


\section{Literature Review}

\subsection{Agency Banking}

Agency banking as a strategy depicts its concept from the Branchless banking model onto which the wordings are used interchangeably. Branchless banking is a distribution channel strategy used for delivering financial services without relying on bank branches (Ivatury, 2011). It represents a cheaper alternative to conventional branch based banking through the use of delivery channels like retail outlets, mobile phones, internet, automated teller machines, Point of Sale devices etc. Agency banking is a type of branchless banking where third parties are involved in performing some of the activities that are traditionally performed in banking halls by bank personnel (Onyango, 2013).

The Consultative Group to Assist the Poor indicates that branchless banking or Agency Banking should comprise of the following elements; use of technology, such as payment cards or mobile phones to identify customers and record transactions electronically and in some cases to allow customers to initiate transactions remotely, use of exclusive or non-exclusive third party outlets such as post offices and small retailers that act as agencies for financial service providers and that enable customers to perform functions that require their physical presence such as cash handling and customer due diligence for account opening, offer service such as basic cash deposit and withdrawal in addition to transactional or payment services and they should have the backing of a government recognized deposit taking institution such as a formally licensed bank. The Agency outlets should structure the above so that customers can use these banking services on a regular basis available during normal business hours and without the need to go into banking halls (Olali, 2014).

This has necessitated the banking regulators to review legislation that seeks to protect customers and also curb forms of money laundering and terrorism financing (Madura, 2008). The controls do not attempt to manage individual banks but impose some discipline so that banks assuming more risks are forced to create their own form of protection against the possibility that such activities should take place ( Onyango,2013).

Most of such institutions are mobiles phone operators which allow the transaction of money contributing a great deal to Branchless Banking. This has increased the financial services outreach to the unbanked population. However, commercial banks cannot take on agency banking without the help of other market players like telecom companies and technology service providers (Ignacio, 2013). Agency banking represents a significant opportunity to reduce transaction costs such as travel for clients by bringing financial services to hard-to-reach and geographically dispersed areas. This is especially true in Africa where some areas are sparsely populated leaving long distances between the customer and the bank. Moreover, in these areas overall literacy levels are fairly low. Also, banks and other financial institutions often do not have sufficient incentive or capacity to establish formal branches in these areas. Obviously, the set-up of agent banks is less costly and more flexible than for traditional bank branches since it reduces the need to invest in staff and physical infrastructure. These views are supported by Aosa (1992).

Agent banks offer similar services as a real bank. This ranges from cash deposits and withdrawals, disbursement and repayment of loans, payment of salaries, pension, transfer of funds, and issuance of mini-bank statements, among others. Berger further argues that, the agent also facilitates new account opening, credit and debit card application, cheque book request, hence eliminating the need for the commercial bank to have branches all over. This is being replicated across the country, especially in rural areas (Berger, 1998).

\subsubsection{Agency Banking Brand Image}

Brand image is the current view of the customers about a brand. The impressions consumers have of a company extend well beyond the product or service the firm provides. According to Porter (1985), brand image is a mental image that reflects the way a brand is perceived, including all the identifying elements, the product or company personality, and the emotions and associations evoked in the consumer's mind. It can be defined as a unique bundle of associations within the minds of target customers. Brand image is perceptions about a brand as reflected by the brand associations held in consumer memory. It is a set of beliefs held about a specific brand. In short, it is nothing but the consumers' perception about the product. It is the manner in which a specific brand is positioned in the market. Brand image conveys emotional value and not just a mental image. Brand image is a composite of perceived quality and esteem dimensions. In other words, brand image is a perception of a brand held in customer memory and reflecting a customer's overall impression. A positive brand image can be considered as a crucial ability of a corporation to hold its market position (Keller, 2013).

A brand image of agency banking is not absolute; it is relative to brand images of competing banks. The customers often form a brand image of a bank from their own banking experience. Furthermore, bank brand image possesses a strategic function. Through strategic marketing activities, the brand image of a bank can be used to help it improve its competitive position. Thus, a favorable agency banking brand image helps strengthen the intentions customers have for selecting an agent bank he or she uses (Da Silva, 2012).

\subsubsection{Operational Structure}

Strategy used by an organization is fundamentally influenced by the operational structure of the organization. It dictates how policies and objectives are established and how resources are allocated. When an organization changes its strategy, the existing organization structure may be ineffective. Though an effective structure, organizations members are able to develop synergies that promote effective strategy implementation. Successful strategy implementation involves 
empowering others to do all the things needed to put the strategy into place and execute it proficiently (Thompson and Strickland, 2007).

Since the strategy implementation process imparts every part of the organization, every manager has to take an active role as a strategy implementer. The most important outcome that leaders, managers and planners should aim from successful strategy implementation is real value added through goal achievement and increased stakeholder satisfaction. Successful strategy implementation in organizations depends on various factors. Strategy implementation is likely to be successful where there is a fit between several organizational elements. These elements include organizational structure, culture, resource allocation, systems and leadership. The culture of an organization defines the social context in which an organization functions. It provides guidance to the organizational members in decision making, time management and energy investment, what kind of people to work for the organization and any other social activity done in the organization (Aosa, 1992). Pearce and Robinson, (2003) states that culture affects the way managers behave in an organization including the decisions they make that affect the relationship between the organization, its strategy and the environment. Appropriate culture will facilitate successful strategy implementation. Staff attitudes and perspectives go a long way towards subverting the firm's plan. Finding and bringing on board the right people to implement and manage change is a significant challenge to the strategy management process in many organizations today. Changes do not implement themselves. It is people that make them happen. Selecting people for key positions by putting a strong management team with the right personnel chemistry and mix of skills is one of the important steps towards successful strategy implementation (Thompson and Strickland, 2007).

\subsubsection{Accessibility to Financial Services}

According to Arora and Ferrand, (2007), reveal that technology adoption especially, in banking systems has shown a great momentum and spread at an unbelievable pace across the world. Considering the importance of banking system's high presence and affordability, there is great potential of using this in agent banking for provision of banking services to unbanked community (Arora and Ferrand, 2007). However, technology systems have associated data and network security risks which make them susceptible for conducting financial transactions. Technology risks regarding information and data security based on applicable models of agent banking have been reported thus creating uncertainty to the clients (Owens, 2006). Owens, (2006), states that financial institutions are required to plan and act for long term development and prosperity of their agents for them to reach the targeted customers at a set population. This requires close coordination and collaboration with agents; providing those opportunities to learn more, to become more efficient and; a fair pricing mechanism for the services provided by the agents (Arora and Ferrand, 2007).

The studies done by National Bank of Rwanda (2014) for monetary policy and financial stability statement stated that access to finance refers to the possibility that individuals or enterprise have to access financial services including credit, deposit, payment, insurance and other risk management services. Securing access to finance for all, including the most vulnerable parts of the population and small entrepreneurs, accelerate inclusive growth. BNR, in its mandate of enhancing and maintaining a stable competitive and inclusive financial sector, has played an important role in facilitating the access to finance in Rwanda through the extension of the banking system and branchless banking solution in rural area and the use information technology.

\subsection{Conceptual Framework}

According to Reichel and Ramney (1987) this is hypothesized model showing the variables under study as conceptualized by the researcher. It is demonstrated by the arrows to show the relationships and interaction between the variables that is, dependent and independent variables. This shows that financial services relates to agency banking.

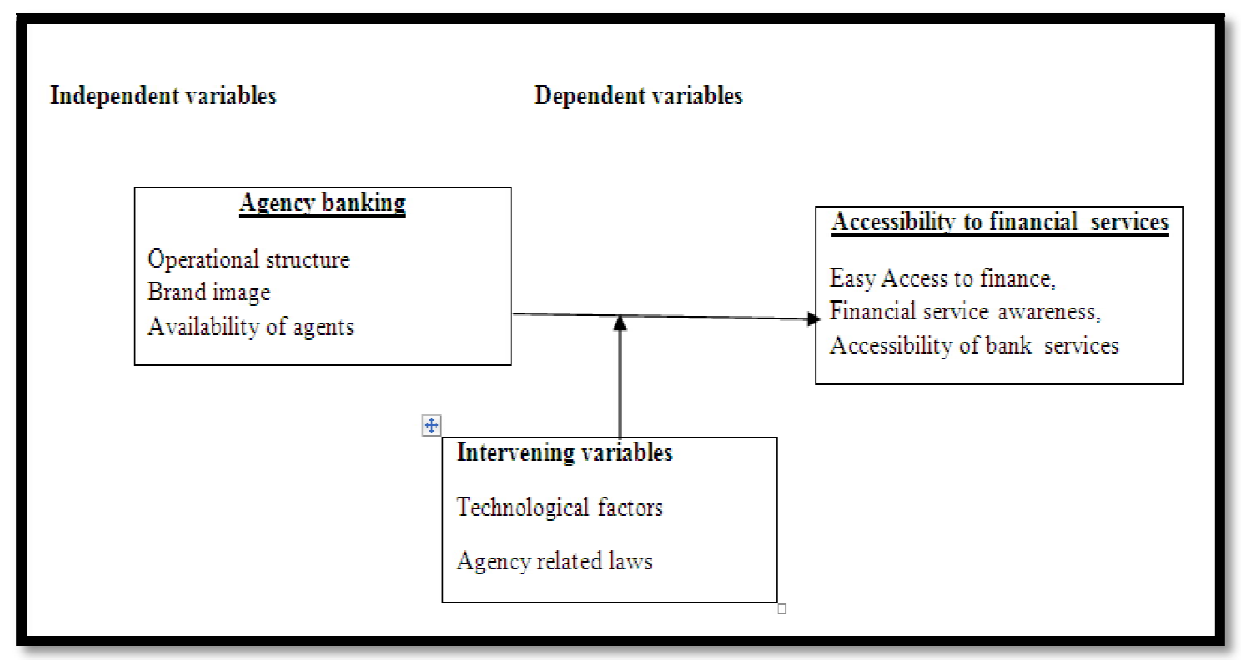

Figure 1: Conceptual Framework 
Figure 1 indicates the relationship between variables; agency banking is determined by operational structure, brand image, availability of agents. Accessibility to Financial services is indicated by easy access to finance, financial service awareness, and accessibility of bank services. There are other factors called intervening variable indicated by technological factors and agency related laws.

\section{Research Methodology}

\subsection{Research Design}

This study employed a descriptive research design. Descriptive study concerns with specific predictions with narration of facts and characteristics concerning individual groups or situations (Cooper and Schindler, 2011).

\subsection{Target Population and Sample Size}

The study population was the operators of all bank agents' outlets. However, the target populations comprised 555 agents of commercial banks in Northern Province of Rwanda. The agents link the populations of remote area and the mother bank in service delivery and ensuring that the target customers get satisfactory services just like they would be served by the staff of the bank at the retail branches.

Yamane was used to determine sample size whereby According to Yamane (1967) provides a simplified formula to calculate sample sizes: $\mathrm{n}=\frac{\mathrm{N}}{1+\mathrm{Ne}^{2}}$ Where $\mathrm{n}$ : sample size, $\mathrm{N}$ : total population, and $\mathrm{e}=$ alpha level, i.e. $\mathrm{e}=0.05$ if the confidence interval is $95 \%$. Total population is 555 using 0.95 confidence interval, the sample size is:

$$
\mathrm{n}=\frac{555}{1+555(0.05)^{2}}=233 \text { People }
$$

\begin{tabular}{|c|c|c|}
\hline Population Category & Target Population & Sample Size \\
\hline Equity bank Rwanda & 175 & 73 \\
\hline Bank of Kigali & 130 & 55 \\
\hline Kenya Commercial Bank Rwanda & 150 & 63 \\
\hline Cogebank & 100 & 42 \\
\hline Total population & 555 & 233 \\
\hline
\end{tabular}

Table 1: Population under Study and Sample Size

Source: Researchers Calculated

\subsection{Sampling Technique}

The researcher used stratified and simple random technique in selecting the respondents in which the respondents were arranged into strata that was according to different bank agents. An important benefit of stratified random sampling is that it ensures the presence of the key subgroup within the sample.

\subsection{Data Collection Methods}

The researcher was used the questionnaires and documentations. Primary data was collected using structured questionnaires served to respondents through direct contact with the agents and drop and pick methods. The methods was chosen because it saves time and cost. Secondary data was obtained through reading relevant publications of other agents in the industry.

\subsubsection{Data Collection Instruments}

The main instrument that was used in collection of data for the study is the questionnaires that were consisted of close ended questions. Secondary sources including books, journals and published reports was consulted to gather enough information for the subject under the study.

\subsubsection{Administration of Data Collection Instrument}

The researcher was distributed the questionnaires to the respondents and waited for them for three days. And then the researcher was made sure that the number of questionnaire distributed has been filled by all respondents or not. After carrying out questionnaires with respondents, the questions were edited and the information gathered was arranged into a meaningful and organized form by coding it. For the research to be more scientific and meaningful, the large quantities of information gathered was condensed, hence facilitating easy analysis and processing of data, coding, tabulation and the analysis of the main findings were presented in chapter four.

The data was analyzed using descriptive statistics in frequency tables. To enable the researcher to gain ground for drawing conclusion, this exercise involved editing, tabulation, using SPSS version 21, and interpretation of findings. 


\section{Research Findings and Discussion}

This chapter specifically presented the analysis and the results of the field data gathered from the banking agents in commercial banks in the Northern Province of Rwanda. The purpose of this study was to determine the effects of agency banking on access to financial services in commercial banks, to establish the relationship between brand images of agency banking and accessibility to financial services in commercial banks, to investigate how operational structure of agency banking influences customer's access to financial services in commercial banks. This formed the basis of the findings presented in this chapter. Descriptive statistics were used to summarize the data and shown response concentrations on the variables of the study. The results were presented and discussed accordingly in the following sections. Coding of the questionnaire was the first task, and then the data was entered into the spread sheet and then transferred it into the SPSS Version 21 for analysis. Statistical tools used were frequency distribution tables, chi-square and correlation. The findings were presented in form of frequency distribution tables, percentages, means and Standard Deviation. Preliminary analyses procedures of cleaning, frequencies, consistency checks, and correction were done on the data obtained. The relationships between independent and dependent variables of the study were determined, explored using chi-square and correlation analysis by conducting the Pearson chi-square and Pearson correlation. The researcher distributed 233 questionnaires to the respondents and received 230 of them back which is $98.7 \%$. According to Mugenda and Mugenda (2003) a 50\% response rate is adequate, $60 \%$ good and above $70 \%$ rated very well. This also concurs with Kothari (2004) assertion that a response rate of $50 \%$ is adequate, while a response rate greater than $72.22 \%$ is very good. This implies that based on this assertions; the response rate in this case of $98.7 \%$ is very good.

\subsection{Demographic Characteristics of Respondents}

The demographic variables used in this case were Gender, Age group and Level of education. Data was collected from people and that is why gender, age and level of education were inquired in order to know the respondent's background. This is because these variables have different preference; taste and purchasing power thus were included as a factor that might play a role in determining the relationship between Agency banking and accessibility to financial services.

A fairly number of agents from each gender was surveyed. Among the 230 people sampled, $61.7 \%$ were male and $38.3 \%$ were female. The respondents were grouped into different age categories who participated in the survey and find that 230 people sampled, $41.6 \%$ were between the age of $21-30$ years, and $11.2 \%$ were between the ages of $0-20$ years, $35.6 \%$ were between the age of 31-40 years and 10.4\% were above the age of 40 years. Moreover the people surveyed, $15.8 \%$ had University qualification, 39.5\% A-level, and 31.4\% had an O-level qualification and $12.1 \%$ had any other qualification.

\subsubsection{Bank Agents}

There was four main agency banking providers in the Rwandan banking industry that are used. The aim was to find out which agency banking provider is mostly preferred. The participants were asked about the agency banking service provider they prefer and they are currently using. The data was analyzed using frequency distribution as per Figure 4.1 Equity bank was ranked the highest with $39.1 \%$ potential users, BK was second with $27.8 \%$ users, KCB was third with $18.7 \%$ users while CogeBank scored the lowest percentage with only $14.3 \%$ users.

\subsection{Presentation of Findings}

The findings were presented under the following headings

\subsubsection{Influence of Operational Structure on Customer's Access to Financial Services}

Strategy used by an organization is fundamentally influenced by the operational structure of the organization. It dictates how policies and objectives are established and how resources are allocated. When an organization changes its strategy, the existing organization structure may be ineffective. Agency banking being a new concept has forced banks to realign or change some of its structures so as to accommodate agency banking, thus this study sought to find out how operational structure of agency banking influences customer's access to financial services in commercial banks in the Northern Province of Rwanda. Table 3 shows the level to which the respondents agree or disagree with some of the factors.

\begin{tabular}{|c|c|c|c|c|c|c|c|}
\hline Variable & $\begin{array}{c}\text { Strongly } \\
\text { Disagree }\end{array}$ & Disagree & Neutral & Agree & $\begin{array}{c}\text { Strongly } \\
\text { Agree }\end{array}$ & Mean & $\begin{array}{c}\text { Std. } \\
\text { Deviation }\end{array}$ \\
\hline & F \% & F \% & F \% & F \% & F \% & & \\
\hline Receiving the customers do not & & & & & & & \\
\hline take too long time due of good & 15 & 7 & 24 & 86 & 98 & 3.748 & 1.4102 \\
\hline System, e.g. deposit, withdraw & 7.7 & 3 & 10.3 & 37 & 42 & & \\
\hline & & & & & & & \\
\hline The costs of opening and & 22 & 6 & 23 & 66 & 113 & 3.817 & 1.29212 \\
\end{tabular}




\begin{tabular}{|c|c|c|c|c|c|c|c|}
\hline Variable & $\begin{array}{c}\text { Strongly } \\
\text { Disagree }\end{array}$ & Disagree & Neutral & Agree & $\begin{array}{c}\text { Strongly } \\
\text { Agree }\end{array}$ & Mean & $\begin{array}{c}\text { Std. } \\
\text { Deviation }\end{array}$ \\
\hline operating an agency are cheap & 9.4 & 2.6 & 9.9 & 28 & 49.8 & & \\
\hline The amount of fees charged on & & & & & & & \\
\hline agency Service is lower & 15 & 7 & 25 & 76 & 107 & 3.622 & 1.45993 \\
\hline compared to go to the bank & 6.1 & 3 & 11 & 33 & 47.2 & & \\
\hline People use agency services to & & & & & & & \\
\hline avoid movement cost to the & 17 & 23 & 23 & 83 & 98 & 3.587 & 1.41693 \\
\hline main bank branch & 7.1 & 3.9 & 9.9 & 37 & 42.1 & & \\
\hline People do payment through & 21 & 9 & 22 & 66 & 112 & 3.791 & 1.31498 \\
\hline agency services such as school, & 9.3 & 3.9 & 9.4 & 28 & 49.4 & & \\
\hline electricity bills, water bills & & & & & & & \\
\hline
\end{tabular}

Table 2: Extent to Which Operational Structure Influence Customer's Access to Financial Services (Source: Field Survey)

The study sought to determine the extent to which operational structure Influence customer's access to financial services was assessed by asking the respondents to their level of agreement on a Likert-scale, ranging from strongly disagree to strongly agree, with statements related to proximity, receiving the customers do not take too long time due of good system. From the findings the study established that $7.7 \%$ of respondents strongly disagreed, $3.0 \%$ of respondents disagreed, $10.3 \%$ of respondents were neutral, and $36.9 \%$ of respondents agreed while $42.1 \%$ of respondents strongly agreed that receiving the customers do not take too long time due of good system as shown by mean of 3.748 and standard deviation of 1.4102. On the question to whether the costs of opening and operating an agency are cheap. From the findings $9.4 \%$ of respondents strongly disagreed, $2.6 \%$ disagreed, $9.9 \%$ were neutral, $28.3 \%$ agreed while $49.8 \%$ strongly agreed that the costs of opening and operating an agency are cheap by mean of 3.817 and standard deviation of 1.29212 . The respondents were also asked if the amount of fees charged on agency Service is lower compared to go to the bank. The findings indicated that $6.4 \%$ of respondents strongly disagreed, $3.0 \%$ of respondents disagreed, $10.7 \%$ were neutral, and $32.6 \%$ of respondents agreed while $47.2 \%$ of respondents strongly agreed that the amount of fees charged on agency Service is lower compared to go to the bank as indicated by mean of 3.622 and standard deviation of 1.4993.

In addition to the statement whether people use agency services to avoid movement cost to the main bank branch. The findings indicated that $7.3 \%$ of respondents strongly disagreed, $3.9 \%$ of respondents disagreed, and $9.9 \%$ were neutral, $36.9 \%$ of respondents agreed while $42.1 \%$ of respondents strongly agreed that people use agency services to avoid movement cost to the main bank branch as shown by mean of 3.587 and standard deviation of 1.41693. Lastly, the respondents were asked if people do payment through agency services such as school, electricity bills, and water bills. The majority of the respondents agreed to the statement whereby $28.3 \%$ of respondents agreed, $49.4 \%$ of respondents strongly agreed, $9.0 \%$ of respondents strongly disagreed, $3.9 \%$ of respondents disagreed, and $9.4 \%$ of respondents were neutral that people do payment through agency services such as school, electricity bills, and water bills as indicated by mean of 3.791 and standard deviation of 1.31498 .

\subsubsection{Relationship between Operational Structure and Accessibility to Financial Services}

The relationship between operational structure of agency banking and accessibility to financial services in commercial banks in the northern province of Rwanda was assessed using Chi-Square Tests and correlation.

\begin{tabular}{|c|c|c|c|}
\hline & Value & Df & Asymp. Sig. (2-sided) \\
\hline Pearson Chi-Square & 34,048 & 12 & 0.001 \\
\hline Likelihood Ratio & 37,271 & 12 & 0 \\
\hline $\begin{array}{c}\text { Linear-by-Linear } \\
\text { Association }\end{array}$ & 1,614 & 1 & 0.204 \\
\hline N of Valid Cases & 230 & & \\
\hline
\end{tabular}

Table 3: Chi-Square Tests between Operational Structure and Accessibility to Financial Services

The study results shows that on overall significance, there is a statistically significant positive relationship between operational structure and accessibility to financial services because the $p$-value of all the measures which is $p=.001$ is less than the set value of $\mathrm{p}<0.05$. Table 3 shows that Tests for Pearson chi-squire on the respondents' mean scores for operational structure and access to financial services revealed that both operational structure and access to financial services had relationship. Thus, adopting Pearson chi-square was conducted using the means for operational structure and access to 
financial services. As stated, our alpha is 0.05, if the "Asymp. Sig. (2-sided)" for the Pearson Chi-Square statistic is less than 0.05 ; there is a relationship between the variables. The Chi-Square significance value is .001 which is less than $p=0.05$, shows there is a relationship between one's agency banking operational structure and accessibility to financial services.

\begin{tabular}{|c|c|c|c|}
\hline \multicolumn{2}{|c|}{} & $\begin{array}{c}\text { Operation } \\
\text { Structure }\end{array}$ & $\begin{array}{c}\text { Accessibility to } \\
\text { Financial Services }\end{array}$ \\
\hline \multirow{2}{*}{ Operation structure } & Pearson Correlation & 1 & $.861^{* *}$ \\
\cline { 2 - 4 } & Sig. (2-tailed) & & .000 \\
\cline { 2 - 4 } & $\mathrm{N}$ & 230 & 230 \\
\hline \multirow{2}{*}{$\begin{array}{c}\text { Accessibility to } \\
\text { financial services }\end{array}$} & Pearson Correlation & $.861^{* *}$ & 1 \\
\cline { 2 - 4 } & Sig. (2-tailed) & .000 & 230 \\
\cline { 2 - 4 } & $\mathrm{N}$ & 230 & \\
\hline
\end{tabular}

Table 4: Correlation between Operational Structure and

Accessibility to Financial Services

**. Correlation Is Significant at the 0.01 Level (2-Tailed)

The Pearson Correlation was conducted using the means for operational structure and access to financial services. The findings were as shown in Table 4 Pearson Correlation analysis established that a positive and statistically significant correlation was established between operational structure and access to financial Services $(r=0.861 ; p<0.01)$. The correlation was very strong, representing an almost perfect correlation between operational structure and access to financial services. Higher access to financial services through bank agent outlets is associated with good operational structure associated with agency banking products and services.

\subsubsection{Effect of Brand Image of Agency Banking on Accessibility to Financial Services}

Brand image is the current view of the customers about a brand. The impressions consumers have of a company extend well beyond the product or service the firm provides. Hence this study sought to establish the relationship between brand images of agency banking and accessibility to financial services. Respondents were asked the extent to which they agree or disagreed with some of those factors and the results are summarized as per Table 5

\begin{tabular}{|c|c|c|c|c|c|c|c|}
\hline Variable & $\begin{array}{l}\text { Strongly } \\
\text { Disagree }\end{array}$ & Disagree & Neutral & Agree & $\begin{array}{c}\text { Strongly } \\
\text { Agree }\end{array}$ & Mean & $\begin{array}{c}\text { Std. } \\
\text { Deviation }\end{array}$ \\
\hline & $\begin{array}{l}\mathrm{F} \\
\%\end{array}$ & $\begin{array}{ll}\mathrm{F} & \%\end{array}$ & $\begin{array}{ll}\mathrm{F} & \%\end{array}$ & $\mathrm{~F} \quad \%$ & F $\%$ & & \\
\hline $\begin{array}{l}\text { Most of clients are aware how } \\
\text { different agency services }\end{array}$ & 15 & 8 & 25 & 73 & 109 & $\begin{array}{c}3,747 \\
8\end{array}$ & 1,40395 \\
\hline I provide work & 6.3 & 3.4 & 10.7 & 32.6 & 47 & & \\
\hline People come to inquire more & 17 & 10 & 23 & 85 & 95 & $\begin{array}{c}3,817 \\
4\end{array}$ & 1,29212 \\
\hline $\begin{array}{l}\text { about the bank's new } \\
\text { developments }\end{array}$ & 7.3 & 4.3 & 9.9 & 36.5 & 42.1 & & \\
\hline $\begin{array}{c}\text { Most of my clients are aware } \\
\text { of the }\end{array}$ & 22 & 5 & 22 & 67 & 114 & $\begin{array}{c}3,691 \\
3\end{array}$ & 1,4097 \\
\hline different fees charged on the & 9.4 & 2.1 & 9.4 & 28.8 & 50.2 & & \\
\hline \multicolumn{8}{|l|}{ various products and services. } \\
\hline Most people are aware of the & 14 & 8 & 25 & 73 & 110 & $\begin{array}{c}3,660 \\
9\end{array}$ & 1,4011 \\
\hline $\begin{array}{l}\text { existence of bank agents' } \\
\text { outlet shops }\end{array}$ & 6 & 3.4 & 10.7 & 32.6 & 47.2 & & \\
\hline $\begin{array}{l}\text { People are aware of the } \\
\text { existence }\end{array}$ & 17 & 7 & 23 & 87 & 96 & $\begin{array}{c}3,878 \\
3\end{array}$ & 1,24787 \\
\hline $\begin{array}{l}\text { of the various product offered } \\
\text { by }\end{array}$ & 7.3 & 3 & 9.9 & 37.3 & 42.5 & & \\
\hline Commercial banks & & & & & & & \\
\hline
\end{tabular}

Table 5: Extent to Which Brand Image of Agency Banking Affects Accessibility to Financial Services

(Source: Field Survey) 
As per Table 5 indicate extend to which respondent agree and disagree to the statement brand image of agency banking affects accessibility to financial services First, the respondents were asked if most of clients are aware how different agency services their provide work. From the findings the results shown that $6.4 \%$ strongly disagreed, 3.4\% disagreed, $10.7 \%$ were neutral, $32.6 \%$ agreed while $46.8 \%$ responded that they strongly agreed that their clients are aware how different agency services they provide work as shown by mean of 3.7478 and standard deviation of 1.40395 . On the question if the people come to inquire more about the bank's new developments. $7.3 \%$ strongly disagreed, $4.3 \%$ disagreed, $9.9 \%$ were neutral, $36.5 \%$ agreed while $42.1 \%$ responded that they strongly agreed that people come to inquire about the bank's new developments as indicated by mean of 3.8174 and standard deviation of 1.29212 . Thirdly, the respondents were asked whether most of my clients are aware of the different fees charged on the various products and services. 9.4\% strongly disagreed, $2.1 \%$ disagreed, $9.4 \%$ were neutral, $28.8 \%$ agreed while $50.2 \%$ strongly agreed that most of my clients are aware of the different fees charged on the various products and services as shown by mean of 3.6913 and standard deviation of 1.4097. Further, respondents were exposed to question that most people are aware of the existence of bank agents' outlet shops. 6.0\% responded that they strongly disagreed, 3.4\% disagreed, 10.7\% were neutral, 32.6\% agreed while $47.2 \%$ strongly agreed that people are aware of the existence of bank agents' outlet shops by the mean of 3.6609 and standard deviation of 1.4011. Lastly, on the questions whether people are aware of the existence of the various product offered by commercial banks. $7.3 \%$ strongly disagreed, 3.0\% disagreed, 9.9\% were neutral, 37.3\% agreed while 42.5\% strongly agreed that people are aware of the existence of the various product offered by commercial banks shown by mean of 3.8783 and standard deviation of 1.24787.

\subsubsection{Relationship Between Brand Image and Accessibility to Financial Services}

The send objective of the study was to establish the relationship between brand images of agency banking and accessibility to financial services in commercial banks in Northern Province. The relationship between brand image and accessibility to financial services was analyzed by using chi-squire and correlation.

\begin{tabular}{|c|c|c|c|}
\hline & Value & Df & Asymp. Sig.(2-sided) \\
\hline Pearson Chi-Square & 30,463 & 12 & 0.002 \\
\hline Likelihood Ratio & 33,801 & 12 & 0.001 \\
\hline $\begin{array}{c}\text { Linear-by-Linear } \\
\text { Association }\end{array}$ & 2,428 & 1 & 0.119 \\
\hline N of Valid Cases & 230 & & \\
\hline
\end{tabular}

Table 6: Chi-Square Tests between Brand Images of Agency Banking and Accessibility to Financial Services

The means for brand image of agency banking and access to financial services were used to compute the Pearson chi square to establish whether the nature and magnitude of the relationship between the two variables. The findings show that there was a statistically significant relationship between brand image of agency banking and accessibility to financial services ( $p=002$ which is less than $p=0.05$ ). The association was positive, indicating that increased access to financial services was attributable to high levels of financial services awareness. The findings of the Pearson chi square analysis were shown as per Table 6.

\begin{tabular}{|c|c|c|c|}
\hline \multicolumn{2}{|c|}{} & Brand Image & Accessibility to Financial Services \\
\hline \multirow{2}{*}{ Brand image } & Pearson Correlation & 1 & $.805^{* *}$ \\
\cline { 2 - 4 } & Sig. (2-tailed) & & .000 \\
\cline { 2 - 4 } & $\mathrm{N}$ & 230 & 230 \\
\hline \multirow{2}{*}{$\begin{array}{c}\text { Accessibility to } \\
\text { financial services }\end{array}$} & Pearson Correlation & $.805^{* *}$ & 1 \\
\cline { 2 - 4 } & Sig. (2-tailed) & .000 & 230 \\
\cline { 2 - 4 } & $\mathrm{N}$ & 230 & \\
\hline
\end{tabular}

Table 7: Correlation between Brand Image of Agency Banking and Accessibility to Financial Services **. Correlation Is Significant at the 0.01 Level (2-Tailed)

The Pearson correction was establish between the two variables and found that there was a statistically significant relationship between brand image of agency banking and accessibility to financial services $(r=0.805 ; p<0.01)$. The correlation was positive, indicating that increased access to financial services was due to high levels of financial services awareness. The findings of the correlation analysis were as shown in Table 7.

\subsubsection{Effects of Agency Banking on Customer's Access to Financial Services}

Respondents were asked the extent to which they agreed or disagreed with some of those factors and the results are summarized as per table 8 


\begin{tabular}{|c|c|c|c|c|c|c|c|}
\hline Variable & $\begin{array}{l}\text { Strongly } \\
\text { Disagree }\end{array}$ & Disagree & Neutral & Agree & $\begin{array}{l}\text { Strongly } \\
\text { Agree }\end{array}$ & Mean & $\begin{array}{c}\text { Std. } \\
\text { Deviation }\end{array}$ \\
\hline & $\mathrm{F} \quad \%$ & F $\%$ & F $\%$ & $\mathrm{~F} \quad \%$ & $\mathrm{~F} \quad \%$ & & \\
\hline Agency banking has made & 21 & 9 & 19 & 66 & 115 & 3,7609 & 1,40468 \\
\hline many people to open savings & 9 & 3.9 & 9.4 & 28 & 49.4 & & \\
\hline \multicolumn{8}{|l|}{ bank accounts } \\
\hline \multicolumn{8}{|l|}{ The number of people coming } \\
\hline $\begin{array}{l}\text { for financial services at the shop } \\
\text { is high due to less difficulties }\end{array}$ & 14 & 8 & 25 & 76 & 107 & 3,8565 & 1,26122 \\
\hline experienced compared to & 6 & 3.4 & 11 & 33 & 47.2 & & \\
\hline \multicolumn{8}{|l|}{ normal banking facilities } \\
\hline $\begin{array}{l}\text { The number of people coming } \\
\text { for }\end{array}$ & 18 & 8 & 23 & 85 & 94 & 3,6174 & 1,45129 \\
\hline $\begin{array}{c}\text { financial advice at the shop is } \\
\text { high }\end{array}$ & 7.7 & 3.4 & 9.9 & 37 & 42.5 & & \\
\hline At the shop, people walk small & 22 & 6 & 23 & 64 & 115 & 3,6304 & 1,40428 \\
\hline distances to get many financial & 9.4 & 2.6 & 9.9 & 29 & 49.4 & & \\
\hline \multicolumn{8}{|l|}{ Services } \\
\hline The number of people using & 15 & 7 & 25 & 73 & 110 & 3,8739 & 1,26654 \\
\hline $\begin{array}{l}\text { remittance and making } \\
\text { payments }\end{array}$ & 6.4 & 3 & 11 & 33 & 47.2 & & \\
\hline through banking agents is high & & & & & & & \\
\hline
\end{tabular}

Table 8: Extent to Which Agency Banking affect Customer's Access to Financial Services (Source: Field Survey)

As per table 8, the respondents were asked to indicate the extent to which they agreed with five statements related to agency banking whether made many people to open savings bank accounts. The study revealed that $9.0 \%$ strongly disagree, $3.9 \%$ disagreed, $9.4 \%$ were neutral, $28.3 \%$ agreed while $49.4 \%$ strongly agreed that agency banking has made many people to open savings bank accounts by mean of 3.7609 and standard deviation of 1.40468 .

On the question whether the number of people coming for financial services at the shop is high due to less difficulties experienced compared to normal banking facilities. The findings shown that $6.0 \%$ of respondents strongly disagreed, $3.4 \%$ disagreed, $10.7 \%$ were neutral, $32.6 \%$ agreed while $47.2 \%$ of respondents strongly agreed that the number of people coming for financial services at the shop is high due to less difficulties experienced compared to normal banking facilities as shown by mean 3.8565 and standard deviation of 1.26122. The respondents were asked if the number of people coming for financial advice at the shop is high. The study indicated that $7.7 \%$ strongly disagreed, $3.4 \%$ disagreed, $9.9 \%$ were neutral, $36.5 \%$ agreed, and $42.5 \%$ strongly agreed that the number of people coming for financial advice at the shop is high by mean of 3.6174 and standard deviation of 1.45129 .On the question if at the shop, people walk small distances to get many financial services, $9.4 \%$ strongly disagreed, $2.6 \%$ disagreed, $9.9 \%$ were neutral, $28.8 \%$ agreed while $49.4 \%$ strongly agreed that at the shop, people walk small distances to get many financial services as shown by mean of 3.6304 and standard deviation of 1.40428 . Lastly, the respondents were asked if the number of people using remittance and making payments through banking agents is high. From the findings the study established that $6.4 \%$ strongly disagreed, $3.0 \%$ disagreed, $10.7 \%$ were neutral, and $32.6 \%$ agreed while $47.2 \%$ strongly agreed that the number of people using remittance and making payments through banking agents is high by mean of 3.8739 and standard deviation of 1.26654. This implies that agency banking is continuously improving leading to significance increased access to financial services in those banks that have rolled up the service due to its convenience and efficiency in operation.

\subsubsection{Relationship between Agency Banking and Accessibility to Financial Services}

The third and final objective of the study was to determine the effects of agency banking on access to financial services in commercial banks in the northern province of Rwanda. In this sub-section, the respondents' views on agency banking and its relationship with access to financial services was analyzed by using chi-squire and correlation. 


\begin{tabular}{|c|c|c|c|}
\hline & Value & Df & Asymp. Sig. (2-sided) \\
\hline Pearson Chi-Square & 34,217 & 12 & 0 \\
\hline Likelihood Ratio & 34,43 & 12 & 0 \\
\hline Linear-by-Linear Association & 3,682 & 1 & 0.064 \\
\hline N of Valid Cases & 230 & & 0 \\
\hline Pearson Chi-Square & 34,217 & 12 & 0 \\
\hline Likelihood Ratio & 34,43 & 12 & 0.064 \\
\hline Linear-by-Linear Association & 3,682 & 1 & \\
\hline N of Valid Cases & 230 & & \\
\hline
\end{tabular}

Table 9: Chi-Square Tests between Agency Banking and Accessibility to Financial Services

A test of chi-squire revealed that the respondent's means scores on availability of agency banking had positive impact on accessibility to financial services. Thus, means for agency banking and access to financial services were used to compute the Pearson chi-squire to determine whether there was a significant relationship between agency banking and accessibility to financial services. The Pearson chi-squire analysis as per table 9 revealed that there was a statistically significant relationship between agency banking and accessibility to financial services $(\mathrm{P}=.000 ; \mathrm{p}<0.05)$. The relationship was positive and very strong, indicating that greater access to financial services was attributable to increased utilization of bank agency services to pay various utility and service bills.

\begin{tabular}{|c|c|c|c|}
\hline \multicolumn{2}{|c|}{} & $\begin{array}{c}\text { Agency } \\
\text { Banking }\end{array}$ & $\begin{array}{c}\text { Accessibility to } \\
\text { Financial Services }\end{array}$ \\
\hline \multirow{2}{*}{ Agency banking } & $\begin{array}{c}\text { Pearson } \\
\text { Correlation }\end{array}$ & 1 & $.774^{* *}$ \\
\cline { 2 - 4 } & Sig. (2-tailed) & & 0 \\
\cline { 2 - 4 } & $\mathrm{N}$ & 230 & 230 \\
\hline Pearson Correlation & $.774^{* *}$ & 1 & \\
\hline Accessibility to financial services & Sig. (2-tailed) & 0 & \\
\cline { 2 - 4 } & $\mathrm{N}$ & 230 & 230 \\
\hline
\end{tabular}

Table 10: Correlation between Agency Banking and Accessibility to Financial Services **. Correlation Is Significant at the 0.01 Level (2-Tailed)

Table 10 shows Pearson correlation results of agency banking and accessibility to financial services. The Pearson correlation analysis revealed that there was a statistically significant relationship between agency banking and accessibility to financial services $(P=0.774 ; p<0.01)$. The relationship was very strong, representing that higher access to financial services was cause to increased utilization of agency banking to pay various utility and service bills. Most of these payment services are provided through POS services or mobile money transfer/ payment services. When compared to the long distances to be covered, the costs of travelling and the long queues, the rural population prefer transacting through the bank agents of the banks in which they hold accounts.

\section{Conclusions and Recommendations}

\subsection{Summary of Findings}

This study had 3 specific objectives namely: to investigate how operational structure of agency banking influences customer's access to financial services , to establish the relationship between brand images of agency banking and accessibility to financial services, to determine the effects of agency banking on access to financial services in commercial banks in the Northern Province of Rwanda. The discussions in the following sections highlight the key findings of the study based on the objectives.

\subsubsection{Findings on Effects of Operational Structure on Customer's Access to Financial Services}

The first objective was to investigate how operational structure of agency banking influences customer's access to financial services. The study found out that commercial bank customers get adequately high good services from agents of commercial banks in the northern province of Rwanda since the means score as per Table 2. Table 3 and Table 4 indicated that $(r=0.861)$ there is a relationship between one's agency banking operational structure and accessibility to financial services.

The first point of contact that establishes a relationship between the rural people and a financial institution is a bank account. Lack of availability of appropriate, low cost, fair and safe financial product and services to certain segments of society, supplied by normal suppliers is financial exclusion. Gallardor (2006) observed that, there are some problems of the financial services in rural areas. Demand of financial services in rural areas has increased but small population size results in high cost and makes financial services less attractive to people in these areas. Info Resources (2008) also highlighted various challenges to rural 
financial services, the most important of these challenges being the high transaction cost. However, with most banks have either completely done away with or considerably lowered the charges associated with deposit and withdraw, the most critical barrier to accessing financial services have been addressed. This has increased the number of people in the rural areas who own bank accounts, and thus can transact at the agency outlets. The challenge of difficult topography and weak configuration of infrastructure that has for a long time discouraged banks from opening ATMs or branches in rural areas has been addressed by establishing agency banking. This has profoundly seen the rural populace avoid traveling long distances to cities for getting financial services, which were not only costly but also tiresome and prohibitive. The effect has been increased access to financial services, hence the positive association between operational structure and access to financial services.

\subsubsection{Findings on the Relationship between Brand Image of Agency Banking and Accessibility to Financial Services}

The second objective was to establish the relationship between brand images of agency banking and accessibility to financial services. The study found out that agency brand image is moderately good since the means score (see Table5) is great. However, it has significant effect in determining the accessibility to financial services. Therefore, on brand images and access to financial services, the study established that (see Table 6 and Table 7) the respondents respectively agreed (79.6\%) that most clients were aware of how different agency services provided work, people go to enquire more about the bank's new developments, people are aware of the existence of the various products offered by commercial banks and most people are aware of the existence of bank agents' outlet shops. There was a significant, positive relationship between brand images and access to financial services. With high levels of awareness on available financial services at the agency outlets, the costs related to the provision of the services as well as transaction costs among other pieces of financial information have increased efforts to ensure that the unbanked rural population has access to financial services.

\subsubsection{Findings on How Agency Banking Influences Customer's Access to Financial Services}

The third and final objective of the study was to determine the effects of agency banking on customer's access to financial services in commercial banks in the Northern Province of Rwanda. The study found out that agency banking is moderately good since indicated by means score and standard deviation as per Table 9 . However, The Pearson chi-squire and Pearson correlation analysis revealed that there was a statistically significant relationship between agent's bank and access to financial services (see Table 9 and Table 10). The relationship was positive and strong $(r=0.774)$, indicating that greater access to financial services was attributable to increased utilization of agency banking to pay various utility and service bills. This implies that with most provider adopting technology-based and cashless payment systems due congestions in the main cash customer service halls, most of the agents of the services have responded positively to such strategies, utilizing such payment services. Most of these payment services are provided through POS services or mobile money transfer/ payment services. When compared to the long distances to be covered, the costs of travelling and the long queues, the rural population prefer transacting through the bank agents of the banks in which they hold accounts. Hence advantages associated with bank services have led to increased access to financial services and by large, financial inclusion.

\subsection{Conclusion}

In line with the first objective of the study which sought to determine the effect of operational structure on accessibility to financial services, the study revealed that good operational structure is a major contributor to customer's access to financial services. The banks do understand application of good operation structure in agency banking, in its business operations. This corresponds with Collins (2010) since the study found that good operational structure in agency banking very great extent influence banks international business operations.

Secondly, the study concludes that there is a positive relationship between bills payments and access to financial services. Advances in innovation that have brought about adoption of telco-money transfer services and the extensive introduction and penetration of point of sale devices have encouraged many service providers and businesses to adopt cashless payments. Due to the convenience associated with cashless payments that save bank clients' time associated with queuing to make payments of some bills such as electricity and water bills as well as the general security related to cashless transactions, many people have adopted such kind of payments whose imperatives include operating a bank account. Thus, with such kind of services as payment of bills, financial inclusion among the rural poor has been enhanced.

The study further concludes that financial services accessibility by customers through banking agencies had a positive impact on financial performance of commercial banks in Rwanda with many of the banking institutions indicating that agency banking had made it easier for them to reach out to many potential clients without investing so much in opening branches hence it's a cost effective measure. Finally, the study concluded that financial services awareness positively influences access to financial services. When people are aware of the available services, are provided with more accurate and up-to-date information on new developments in agency banking segment and know where to get the services, their access to financial services increases thus enhanced financial inclusion.

\subsection{Recommendations}

Commercial banks should ride on the successes made in agency banking to scale up access to financial services hence financial inclusion by opening up more outlet networks to considerably reduce the distances covered by the rural poor. Better geographic outreach can remove distance as a barrier to financial access for both the bank and the client, thus allowing banks 
to be more responsive and less intimidating to their deposit customers. This should be augmented by allowing the agents to perform other services such as collection of cheques to enhance financial access and inclusion.

Secondly, the study recommends improvement of brand image of all agent banks operating in the retail market. The study further recommends that information and awareness should be put in public to build confidence and trust in agency banking as a secure, efficient and modern way of banking. Riding on the positive influence of customer's access to financial services, commercial banks and other financial institutions should make careful efforts to institutionalize customer education programmers that will raise awareness among not only existing clients but also potential customers. This has potential to increase take up of financial services thus benefiting both the client and the financial institution.

\subsection{Suggestions for Further Studies}

The study relied on self-reported data mainly from the commercial bank perspective alone and used a single industry setting. Further research could seek to address this limitation by use of multiple industries setting such as telecommunication companies to conduct their studies and this would enhance the validity and generalization of the research findings.

Although the bank agents were fit for giving reliable data, there is a possibility that the information from these agents was not the only source of information about agency banking and accessibility to financial services. It may be vital to use both information from the bank managers and compare with the views of the other stakeholders like the competitors and suppliers. Possibilities of exaggerated results from self-reported data may also exist where secondary data is not available for further validation. To handle this limitation, future research can combine the views of managers, customers, suppliers, competitors and other relevant organization stakeholders.

\section{References}

i. Aduda, J., \& Kalunda, E. (2012). Financial Inclusion and Financial Sector Stability with reference to Kenya: A Review of Literature. Journal of Applied Finance \& Banking, 2 (6), 95-120.

ii. Al-Ghamdi, S. M. (1998). Obstacles to successful strategy implementation of strategic decisions: the British experience; European Business Review, 98(6), 327-422.

iii. Arora, S., \& Ferrand, D. (2007). Meeting the Challenge of Creating an Inclusive Financial Sector. Paper Presented During DFID and HM Treasury Financial Inclusion Conference, London. The International Journal of Business \& Management, 4(20), 2321-8916.

iv. Aosa, E. (1992). An Empirical Investigation of aspects of strategy Implementation with large private manufacturing companies. Nairobi: act press.

v. Berger, M. (1998). Poor Economics. New York: Perseus Books.

vi. BNR, (2013). The report on agency banking in Rwanda. Kigali: Central bank of Rwanda

vii. Bossidy, L., \& Chavan, R. (2002). Execution, Crown Business. New York: Dover.

viii. Bold, C. (2011). Branchless Banking in South Africa. Consultative Group To Assist the Poor (CGAP). Pretoria: act press

ix. Bryson, J. M. (1995). Strategic Planning for Non-profit organizations, Revised edition.New York: Jossy Brass.

x. Byars, L. L. (1996). Strategic management Formulation and Implementation. England: HarperCollins Publishers

xi. Central Bank of Kenya, (2010). Report on the knowledge on agency banking to Braziland Columbia. Nairobi: Nation bank of Kenya

xii. Central Bank of Rwanda, (2014). Report on monetary policy and financial stability statement. Kigali: National Bank of Rwanda

xiii. Commercial Banks, (2015). The report on agency banking in Rwanda.Kigali: Central Bank of Rwanda

xiv. CGAP. (2010).Understanding Branchless Banking Business Models International Experiences: Washington D.C: Focus Note No. 43

xv. Charles, G. N. (2014). Assessment of Factors Influencing Adoption of Agency Banking in Kenya.jpurnal

xvi. management research and Business strategy, 4(3):2319-345

xvii. Christopher, S. (2002).Measuring Financial Inclusion: The Global Findex Database. Washington, D.C: World Bank Policy Research Paper 6025

xviii. Cohen, V. (2013). Financial Development, Financial Fragility, and Growth. Journal of Money, Credit, and Banking, 38(4): 1051-76.

xix. Cook \& Campbell (2000). Questionnaire Construction and Question Writing for Research. Western Cape: Sterling Press.

xx. Cooper, D.R., \& Schindler, P.M. (2006), Business Research Methods, 9th Edition, New Delhi: McGraw-Hill International Edition.

xxi. Da Silva, R. V. (2012). Cognitive, affective and conative behavioral responses in retail corporate branding. Journal of Product and Brand Management, 15(5), 293305.

xxii. Equity Bank Rwanda, (2015).The annual report on the agency banking in Rwanda. Kigali: National bank of Rwanda.

xxiii. Francis, K. (2015). The effects of agency banking on access to financial Services. Journal management research and Business strategy 4(3):2319-345. 
xxiv. Gakenia, C. (2008). Strategy Implementation by Kenya Commercial Bank GroupLtd. Nairobi: Central bank of Kenya.

xxv. Galbraith, J.R., \& Nathanson, D. A. (1978). Strategy Implementation. The Role of Structure and Process. St. Pauls Minesota (MN): West Publishing Company.

xxvi. Gardner, P. O. (2000). Finance,Institutions and Economic Development. International Journal of Finance and Economics, 11(3): 245-60.

xxvii. George, J.R., \& Muller, D. A. (2003). Strategy Implementation. The Role of Structure and Process. St. Pauls Minesota (MN): West Publishing Company.

xxviii. George, D., \& Mallery, P. (2003). SPSS for Windows step by step: A simple guide and reference 11.0 update $4^{\text {th }}$ ed. Boston: Allyn \& Bacon

xxix. Harper, W. B., \& Ralph, W. S. (1989). Marketing Research, 7thed. Boston: Library of congress.

xxx. Ignacio, E. (2013).Technology management. Encyclopedia of Management. Ed. Marilyn Helms, D.B.A. $5^{\text {th }}$ ed. Detroit (892-899): Boston: Library of congress.

xxxi. Ivatury, G. (2011). Using Technology to Build Inclusive Financial Systems.: Washington, D.C.: CGAP Focus Note No. 3.

xxxii. Ivatury, G., \& Mas, I. (2008). The early experience with branchless banking. Washington, D.C: CGAP Focus Note No. 46 .

xxxiii. James, S. (2008). Management. NY: Pearson Education Incorporation.

xxxiv. Keller, K. L. (2013). Conceptualizing, measuring, and managing customer-basedbrand equity. Journal of Marketing, 57(1), 1-22.

xxxv. Kimeli, F.K. (2008). Strategy Implementation and its challenges in public corporations:. Unpublished Master's thesis, University of Nairobi.

xxxvi. Kothari, C. R.(1985).Research Methodology; Methods and Techniques. Revised $\quad$ 2ndEdition. New Delhi: New Age International (P) Limited.

xxxvii. Lingle, S., \& Schiemann, T. (2014). Meeting the Challenge of Strategic Change. Harvard Business Review.8 (4):254-270.

xxxviii. Madura, M. (2008). Fundamentals of Financial Management. England: Horne Publishers.

xxxix. Mugambi, E. (2013). Provision of Electronic Banking in the UK and the Republic of Ireland. The International Journal of Bank Marketing, 17(2):240-260.

xl. Mugenda, O.M., \& Mugenda, A.G. (1999). Research Methods, Qualitative and Quantitative Approaches: Nairobi: Acts Press.

xli. Mutie,J. M., Julius, B., \& Jared, M. (2015). Investigation on Importance of Agency Banking in Provision of

xlii. Banking Services in Kenya. Jurnal of Business and Social Sciences, 5(2):187-204.

xliii. Mulupi, M. (2011). Cognitive, affective and conative behavioral responses in retail corporate branding. Journal of Product and Brand Management, 15(5), 293305.

xliv. Muthiga, F. A. (2014). Strategy implementation and its challenges in non-profit organizationsin Kenya. Unpublished Master's thesis, University of Nairobi.

xlv. Olali, B. (2014). Strategic Planning and Financial Performance. A meta-analyticalreview, Journal of Management studies. 28(7), 287294.

xlvi. Onyango, P. (2013). A survey of consumer adoption of mobile phone banking in Kenya. Unpublished Master's thesis, University of Nairobi.

xlvii. Owens, J. (2006). RBAP Text-A-Payment And G-Cash Cash-In/ Cash-Out Services: Innovative Banking Services At Your Fingertips.

xlviii. Pearce, J. A., \& Robinson, R. B. (2003). Strategic Management; formulation implementation and control. New York: McGraw Hill Irw.

xlix. Peter, M.K. (2015). Effect of agency banking on financial performance of commercial banks in Rwanda. ournal of Business and Social Sciences, 5(1):181-201.

l. Plok, R. (2009).Commercial bank interest margins and profitability: Evidence for some EU countries.

li. CISEP, Portugal: Porto Working Paper Series.

lii. Polit, M., \& Becks, R. (2008). How Management Information can Improve Strategic Decision Making. England: Marakon Associates.

liii. Porter, M. E. (1985). What is Competitive Strategy? Harvard Business Review, 64(3): 225-251.

liv. Reichel, M., \& Ramney, M.A, (1987). Conceptual frameworks for bibliographic education: theory into practice. Littleton, Colo: Libraries Unlimited.

lv. Rogers, E.M, (1995). Diffusion of Innovations (4th Edition). New York: The free press.

lvi. Rogers, E.M. (1976). New Product Adoption and Diffusion. Journal of consumer research, 2(3): 290-301.

lvii. Rousseau, M. (2011). Inflation Thresholds and the Finance-Growth Nexus.Journal of International Money and Finance, 21(6): 777-93.

lviii. Stephen, R. (1973). The Economic Theory of Agency: The Principal's Problem, American Economic Review

lix. 63(2):134-139. 
lx. Tarazi, M., \& Breloff, P. (2011). Regulating Banking Agents. Focus note CGAP, 68, 2.

lxi. Thompson, A. A., \& Strickland, A. J.(2007). Grafting and Implementing Strategy.Boston: Irwing McGraw Hill.

lxii. Wireless Intelligence, (2007). Using Technology to Build Inclusive Financial Systems. Washington, D.C: CGAP Focus Note No. 3.

lxiii. World Bank, (2006). Africa Region: Making Finance Work for Africa. Washington DC: World Bank Publications. lxiv. Yamane, T. (1967). Statistics: An Introductory Analysis, 2nd Ed., New York: Harper and Row. 